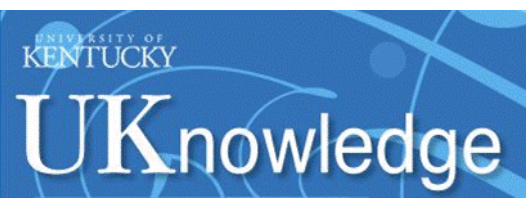

Kentucky Law Journal

\title{
Reflections on the Technicolor Right to Association in American Labor and Employment Law
}

Paul M. Secunda

University of Mississippi

Follow this and additional works at: https://uknowledge.uky.edu/klj

Part of the Labor and Employment Law Commons

Right click to open a feedback form in a new tab to let us know how this document benefits you.

\section{Recommended Citation}

Secunda, Paul M. (2008) "Reflections on the Technicolor Right to Association in American Labor and Employment Law," Kentucky Law Journal: Vol. 96: Iss. 3, Article 2.

Available at: https://uknowledge.uky.edu/klj/vol96/iss3/2

This Article is brought to you for free and open access by the Law Journals at UKnowledge. It has been accepted for inclusion in Kentucky Law Journal by an authorized editor of UKnowledge. For more information, please contact UKnowledge@lsv.uky.edu. 


\begin{tabular}{lll}
\hline VOLUME 96 & $2007-2008$ & NUMBER 3 \\
\hline
\end{tabular}

A R T I C L E S

\title{
Reflections on the Technicolor Right to Association in American Labor and Employment Law
}

\begin{abstract}
Paul M. Secunda
It is not disputed that to compel a teacher to disclose his every associational tie is to impair that teacher's right of free association ..., a right which, like free speech, lies at the foundation of a free society. ${ }^{2}$
\end{abstract}

\section{INTRODUCTION}

$\mathrm{O}$ NE of the least understood of all labor and employment rights in the United States today is the right to association. There are a number of reasons for the enigmatic nature of this right. First, the "right to association" is not found expressly in the United States Constitution, and therefore has had to be necessarily implied from numerous provisions throughout the Constitution. As a result, there is not one form of constitutional associational right, but instead there are rights as diverse as the rights to political association, workplace association, intimate association, and expressive association.

Second, to the extent that federal constitutional protections exist in the workplace for the right to association, they primarily apply to public employees in the United States because of the "state action" requirement. ${ }^{3}$ This generally only occurs when the employer is a public entity like a federal, state, or local government employer. Consequently, much of the constitutional right to association that potentially applies to the workplace

I Jessie D. Puckett Jr., Lecturer and Assistant Professor of Law, University of Mississippi School of Law. I thank Professor Mathew Finkin of the University of Illinois for his generosity and support of this and other projects. All errors and omissions are mine alone.

2 Shelton v. Tucker, 364 U.S. $479,485-86$ (1960).

3 Nancy Levit, Preemption of Section 1983 by Title VII: An Unwarranted Deprivation of Remedies, 15 Hoftsra L. Rev. 265, 290-91 (1987) (noting court holding that giving public employees more constitutional rights "finds its justification in the 'state action requirement' of the Fourteenth Amendment which mandates this result") (quoting Skadegaard v. Farrell, 578 F. Supp. 1209 , 1218 (D. N.J. 1984)). 
only actually impacts twenty-one million workers or about $16.5 \%$ of the American workforce. ${ }^{4}$

Third, the right to association is most palpable in the private labor and employment context in the form of the right to form, assist, and join a labor organization, to bargain collectively with a representative of one's own choosing, and to engage in concerted activities for mutual aid and protection under federal statutory law, Section 7 of the National Labor Relations Act. ${ }^{5}$ Nevertheless, only about seven to eight percent of the private American workforce is unionized, ${ }^{6}$ and perhaps slightly more is seeking to unionize at any given time, meaning that these statutory rights have far less influence today than in decades past. ${ }^{7}$ Additionally, Professor Garcia has persuasively argued that even existing labor rights are currently under siege in the current, unfriendly political and judicial environment. ${ }^{8}$

Finally, non-union private sector workers may try to secure associational rights in the workplace through various state statutory and common law schemes, like under the tort for wrongful discharge in violation of public

4 See U.S. Dept. of Commerce, U.S. Census Bureau, Statistical Abstract of the United States 298 (2004-2005) (Table No. 453) (figure from 2002); Joseph R. Grodin, June M. Weisberger \& Martin H. Malin, Public Sector Employment: Cases and Materials I (2004).

529 U.S.C. $\$ 157$ (2007). Furthermore, courts have long held that constitutional freedom of association protection extends to activities in organizations such as labor unions. See Smith v. Arkansas Highway Employees, 44 I U.S. 463 (1979) (per curiam) (recognizing the existence of constitutional protection for associations involving union activity); Thomas v. Collins, 323 U.S. 5 I 6 ( I945); see also Ruben J. Garcia, Labor's Fragile Freedom of Association Post-g/II, 8 U. PA. J. LAB. \& EMP. L. 283, 285 (2006) ("The right of private sector workers to picket, speak, and assemble is protected, within limits, against governmental interference by the First Amendment"). "The First Amendment does not, however, impose on public employers any affirmative obligation to listen to, respond to, or engage in collective bargaining with a public sector union or association." William A. Herbert, The First Amendment and Public Sector Labor Relations, I9 LAB. LAW. 325, 341-42 (2004).

6 "While unions represented $36.5 \%$ of public sector workers in 2005 , a rate that has generally remained at that level since 1983 , unions represented a mere $7.8 \%$ of private sector workers in 2005, half of the percentage they represented in 1983." Kye D. Pawlenko, Recvaluating Inter-Union Competition: A Proposal to Resurrect Rival Unionism, 8 U. PA. J. LAB. \& EMP. L. 65 I , 654 (2006) (citing Bureau of Labor Statistics, United States Department of Labor, USDL 06-99, Union Members in 2005 (Jan. 20, 2006), available at http://www.bls.gov/news. release/archives/union2_oI 202006.pdf) [hereinafter Bureau of Labor Statistics of 2005].

7 The overall union density in the United States in now $12 \%$, but as recently as 1983 , rates were nearly twice as much. See Bureau of Labor Statistics, United States Department of Labor, USDL 07-1 13, Union Members in 2006 (Jan. 25, 2007), available at http://www.bls. gov/news.release/archives/union2_01252007.pdf ("The union membership rate has steadily declined from 20 . I percent in 1983 , the first year for which comparable union data are available") [hereinafter Bureau of Labor Statistics of 2006].

8 Garcia, supra note 5 , at 284 (maintaining that, "the post-9/I I environment of fear and insecurity has weakened labor's freedom of association through actions by Congress and the President, and through decisions of the courts and the National Labor Relations Board"). 
policy. ${ }^{9}$ By and large, however, these attempts have proven unsuccessful in an American employment system dominated by the employer-friendly employment-at-will doctrine. ${ }^{10}$

In short, although many different forms of rights to association exist in the United States workplace, the actual coverage for workers is a patchwork of protections that apply sometimes and not others, depending largely on factors such as whether one works for a public or private employer and whether one is in a unionized or non-unionized work environment. ${ }^{11}$ The consequence of this state of affairs is that American workers may have fewer rights to association than many of their international counterparts in the industrialized world.

9 The Novosel case provides an example where the court attempted to recognize a right to speech and association for a private employee, Novosel v. Nationvide Ins. Co., 72 I F.2d 894 (3d Cir. 1983), but its ruling has since been implicitly overruled. See Borse v. Piece Goods Shop, Inc., 963 F.2d 61 I (3rd Cir. 1992) (retreating from Novose/'s interpretation of Pennsylvania's constitution); Paul v. Lankenau Hosp., 569 A.2d 346 (Pa. 1990) (disapproving of Novose/s interpretation of the Pennsylvania Constitution).

Io Under the doctrine of employment-at-will, employers may terminate an employee for good cause, bad cause, or no cause at all, as long as the reason is not illegal (e.g, under federal, state, or local antidiscrimination law). Similarly, the reciprocal right of the employee is the ability to leave employment without giving notice to their employer. This rule evolved from a treatise by H.G. Wood in 1877 . Wood asserted:

With us the rule is inflexible, that a general or indefinite hiring is prima facie a hiring at will, and if the servant seeks to make it out a yearly hiring, the burden is upon him to establish it by proof .... [A]n indefinite hiring .... is determinable at the will of either party ....

H. G. Wood, A Treatise on the Law of Master and Servant \& 134, at 272 (1877). This state of affairs is in contrast to the employment system in most industrialized parts of the world where the standard for dismissal is just or good cause. See Steven L. Willborn, Et. Al., Employment Law: Cases \& Materials i99-20 i (4th ed. 2007) ("The United States is unique in the industrialized world in having at its basic rule that workers can be fired for any reason without any notice").

I I One recalls here the criticism in Garcetti v. Ceballos, $126 \mathrm{~S}$. Ct. 195 I (2006), by Justice Souter in his dissent concerning federal and state whistle-blowing statutes in the United States:

[S]peech addressing official wrongdoing may well fall outside protected whistle-blowing, defined in the classic sense of exposing an official's fault to a third party or to the public; the teacher in Givhan, for example, who raised the issue of unconstitutional hiring bias, would not have qualified as that sort of whistle-blower, for she was fired after a private conversation with the school principal. In any event, the combined variants of statutory whistle-blower definitions and protections add up to a patchwork, not a showing that worries may be remitted to legislatures for relief.

Id. at 1970 (Souter, J., dissenting) (citing Givhan v. Western Line Consol. School Dist., 439 U.S. 410 ( 1979$)$ ). 
This article will reflect on some of the various workplace situations where rights to association are implicated and the problems of application that derive from these scenarios. Some of these examples involve situations where employees depend on rights to association to defend themselves against arbitrary employer action and overreaching, but other associational rights discussed below inhere in the employer and may be utilized to exclude unwanted employees from an employee organization, thereby undermining employees' rights to association further.

The solution seems to be for Congress to adopt a uniform federal law to protect the associational rights of all employees in the workplace. My project is therefore similar to the one undertaken by Justice Souter in dissent in Garcetti v. Ceballos ${ }^{12}$ in the whistle-blowing/free speech context:

My point is not to disparage particular statutes ..., but merely to show the current understanding of statutory protection: individuals doing the same sorts of governmental jobs and saying the same sorts of things addressed to civic concerns will get different protection depending on the local, state, or federal jurisdictions that happened to employ them. ${ }^{13}$

To address these concerns, this article is divided into five parts based on the different types of associational rights in the labor and employment context. Part I discusses the use of the right to association to protect public employees from political discrimination and other forms of associational discrimination. ${ }^{14}$ Part II explores emerging intimate association rights to protect workers' sexual privacy from employer interference. ${ }^{15}$ Part III then turns the tables and considers how American employers may use the right of expressive association to exclude employees whose mere presence implies support for controversial or unpopular views. ${ }^{16}$ Part IV then suggests a federal stature, the Freedom of Association in the Workplace Act (FAWA), which would better secure the basic freedom of association to all workers and make uniform this most fundamental of civil liberties. ${ }^{17}$

\section{The Right to Association in the American Public Workplace}

Although the right to association is not found within the text of the First Amendment to the United States Constitution, ${ }^{18}$ such a right has

12 Garcetti, I 26 S. Ct. 195 I (2006).

13 Id. at 197 I (Souter, J., dissenting).

14 See infra notes $18-80$ and accompanying text.

15 See infra notes 81-105 and accompanying text.

16 See infra notes $106-43$ and accompanying text.

17 See infra notes $144-57$ and accompanying text.

18 U.S. Const. amend. I "Congress shall make no law respecting an establishment of religion, or prohibiting the free exercise thereof; or abridging the freedom of speech, or of the press; or the right of the people peaceably to assemble, and to petition the Government for a 
nevertheless been implicitly found to be a fundamental constitutional right by the United States Supreme Court. ${ }^{19}$ In short, this is because the ability to associate with others increases one's ability to engage in civil liberties protected by the Constitution. ${ }^{20}$ In this regard, the Supreme Court has commented that an "individual's freedom to speak, to worship, and to petition the government for the redress of grievances could not be vigorously protected from interference by the State unless a correlative freedom to engage in group effort toward those ends were not also guaranteed." 21

The actual scope of the right to association in the labor and employment context is based on the notion, sometimes referred to as the doctrine of unconstitutional conditions, that a public employer may not take adverse employment action against a public employee on a basis that infringes his or her constitutional rights. ${ }^{22}$ Thus, although many public employees continue to be at-will employees, ${ }^{23}$ they cannot be terminated, demoted, transferred, or subjected to other adverse employment actions, for exercising their constitutional rights.

At one time in its history, the United States Supreme Court held that government benefits were mere privileges that could be withheld or limited on any condition. ${ }^{24}$ The American jurist, Justice Oliver Wendell Holmes, famously wrote in the employment context that a person "may have a constitutional right to talk politics, but he has no constitutional

redress of grievances").

I9 See Roberts v. U.S. Jaycees, 468 U.S. 609, 622 (1984) ("[W]e have long understood as implicit in the right to engage in activities protected by the First Amendment a corresponding right to associate with others in pursuit of a wide variety of political, social, economic, educational, religious, and cultural ends"); see also NAACP v. Alabama ex. rel. Patterson, 357 U.S. 449, 461 (1958) (labeling right to association as an indispensable part of liberty on the same plane as the rights to speech or press).

20 Patterson, 357 U.S. at 460. Professor Chemerinsky explains more practically that because groups have resources in human capital and money, such groups enhance an individual's freedom to engage in protected constitutional activities. See Erwin Chemerinsky, Constitutional Law: Principles and Policies 1 i 3 (2d ed. 2002); see also New York State Club Assoc. v. City of New York, 487 U.S. I, I3 ( I988) ("The ability and the opportunity to combine with others to advance one's view is a powerful practical means of ensuring the perpetuation of the freedoms the First Amendment has guaranteed to individuals as against the government").

2 I Roberts, 468 U.S. at 622.

22 Perry v. Sindermann, 408 U.S. 593, 597 (1972).

23 However, a large number of public employees in the United States also have just cause protection under either a collective bargaining contract or civil service laws. For instance, as of 2006, 36.2\% of public sector employees were union members. See Bureau of Labor Statistics of 2006, supra note 7. Additionally, many federal civil service workers may only be terminated for cause that promotes the efficiency of the civil service. 5 U.S.C. $\$ 7513$ (a) (2007).

24 See, e.g., People v. Crane, 108 N.E. 427, 430 (Mass. 1892) (per Cardozo, J.), aff'd, 239 U.S. 195 (1915) (limiting public employment to citizens on the theory that "[w]hatever is a privilege, rather than a right, may be made dependent on citizenship"). 
right to be a policeman."25 But just as American case law has now made clear that a rights/privilege distinction no longer exists, ${ }^{26}$ the Court has also arrived at this same conclusion in the employment context. ${ }^{27}$ For instance, in the landmark public employment case of Keyishian v. Board of Regents, ${ }^{28}$ the Supreme Court stated emphatically: " [T] public employment which may be denied altogether may be subjected to any conditions, regardless of how unreasonable, has been uniformly rejected." 29

Thus, the government "may not deny a benefit to a person on a basis that infringes his constitutionally protected interests-especially, his interest in freedom of speech." ${ }^{30}$ As the Court observed in Perry: "For if the government could deny a benefit to a person because of his constitutionally protected speech or associations, his exercise of those freedoms would in effect be penalized and inhibited," 31 and "“produce a result which [it] could not command directly." 32

The doctrine of unconstitutional conditions has also been thoroughly explored in the First Amendment context as justification for greater governmental power in its role as public employer. Justice Marshall observed in Pickering $v$. Board of Education" :[I]t cannot be gainsaid that the State has interests as an employer in regulating the speech of its employees that differ significantly from those it possesses in connection

25 See McAuliffe v. Mayor and City of New Bedford, 29 N.E. 517 (Mass. 1892); see also Adler v. Bd. of Educ., 342 U.S. 485,496 (1952) (finding "no constitutional infirmity" to a law which required public employees to declare past and present Communist affiliation).

26 See Sugarman v. Dougall, 413 U.S. 634, 644 (1973) ("[T] his Court now has rejected the concept that constitutional rights turn upon whether a governmental benefit is characterized as a 'right' or as a 'privilege'") (quoting Graham v. Richardson, 403 U.S. 365, 374 ( I 97 I )).

27 See Keyishian v. Bd. of Regents, 385 U.S. 589,605 (1967).

28 Id.

29 See id. at 605-06 (quoting Keyishian v. Board of Regents, 345 F.2d 236, 239 (2d Cir. 1965)); see also Perry v. Sindermann, 408 U.S. 593, 597 (1972) ("For at least a quarter-century, this Court has made clear that even though a person has no 'right' to a valuable governmental benefit and even though the government may deny him the benefit for any number of reasons, there are some reasons upon which government may not rely"); Sherbert v. Verner, 374 U.S. 398,404 ( 1963 ) (in the unemployment compensation and free exercise of religion context stating that, "[i]t is too late in the day to doubt that the liberties of religion and expression may be infringed by the denial of or placing of conditions upon a benefit or privilege").

30 Perry, 408 U.S. at 597.

31 See id.

32 See id. (quoting Speiser v. Randall, 357 U.S. 513, 526 (1958)); see also Laird v. Tatum, 408 U.S. I, I I ( 1972) ("[C]onstitutional violations may arise from the deterrent, or 'chilling', effect of governmental regulations that fall short of a direct prohibition against the exercise of First Amendment rights"); Jason Mazzone, The Waiver Paradox, 97 Nw. U. L. Rev. 801,806 (2003) ("The doctrine of unconstitutional conditions rejects the notion that the government's power to grant a benefit includes the lesser power to attach any conditions at all to receiving the benefit").

33 Pickering v. Bd. of Educ., 39 I U.S. 563 (1968). 
with regulation of the speech of the citizenry in general." 34 And although Justice Marshall in Pickering did not cite to any precedent to support his assertion, the Supreme Court on numerous occasions since has affirmed this view of the varying degrees of power that government has depending upon the capacity in which the government is acting. ${ }^{35}$ For example, in her opinion for the Court in Board of County Commissioners v. Umbehr, ${ }^{36}$ Justice O'Connor explained that a government employee's close relationship with the government requires a balancing of important free speech and government interests. ${ }^{37}$ In such relationships, "[t]he government needs to be free to terminate both employees and contractors for poor performance, to improve the efficiency, efficacy, and responsiveness of service to the public, and to prevent the appearance of corruption." ${ }^{38}$ Similarly, Justice

34 Id. at 568 (emphasis added); see also Rutan v. Republican Party of Illinois, 497 U.S. 62, 94 (1990) (Scalia, J., dissenting) ("The restrictions that the Constitution places upon the government in its capacity as lawmaker, i.e., as the regulator of private conduct, are not the same as the restrictions it places upon the government in its capacity as employer"); Brown v. Glines, 444 U.S. $348,356-357$ n.13 ( 1980 ) ("A governmental employer may subject its employees to such special restrictions on free expression as are reasonably necessary to promote effective government"); Mark Tushnet, The Possibilities of Comparative Constitutional Law, 108 YALE L.J. I 225, 1250 ( I999) ("[A] balancing approach that would not be used when the government acts as regulator is appropriate when the government acts as employer"). For an interesting conception of the different roles government play, see generally ROBERT C. POST, Constrrutronal Domains: Democracy, Community, Management (i995) (dividing the "social domain" into three parts: the domain of democracy and public discourse, the domain of management, and the domain of community).

35 See Waters v. Churchill, 5 I I U.S. 66I, 671-72 (1994) (plurality opinion) ("We have never explicitly answered this question [about the government's dual roles,] though we have always assumed that its premise is correct-that the government as employer indeed has far broader powers than does the government as sovereign") (citing Pickering, 39 I U.S. at 568; Civil Service Comm'n v. Letter Carriers, 413 U.S. 548, 564 ( 1973)); Bd. of Educ. of Kiryas Joel Vill. Sch. Dist. v. Grumet, 512 U.S. 687, 7 18 (1994) (O'Connor, J., concurring) ("We have ... no one Free Speech Clause test. We have different tests for content-based speech restrictions, for content-neutral speech restrictions, for restrictions imposed by the government acting as employer, for restrictions in nonpublic fora, and so on"); Connick v. Myers, 46I U.S. 138, I47 (1983)). See also Eugene Volokh, A Common-Law Model for Religious Exemptions, 46 UCLA L. REv. 1465 , 1497 ( 1999 ) ("Administrative efficiency is generally not considered a compelling interest under strict scrutiny, which may be one reason that free speech cases have explicitly adopted a more deferential standard for government-as-employer regulations, instead of purporting to apply strict scrutiny").

36 Bd. of County Comm'rs v. Umbehr, 518 U.S. 668 (1996).

37 See id. at 680.

38 See id. at 674; see also Waters, 5 I I U.S. at 674-75:

[T] he extra power the government has in this area comes from the nature of the government's mission as employer. Government agencies are charged by law with doing particular tasks. Agencies hire employees to help do those tasks as effectively and efficiently as possible. When someone who is paid a salary so that she will contribute to the agency's effective operation begins to do or say things that detract from the 
Powell explained in his concurring opinion in Amett $v$. Kennedy that "the Government's interest, and hence the public's interest, is the maintenance of employee efficiency and discipline .... To this end, the Government, as an employer, must have wide discretion and control over the management of its personnel and internal affairs." ${ }^{39}$ Last, in her plurality decision in Waters $v$. Churchill, Justice O'Connor juxtaposed the two roles that government plays by describing certain First Amendment doctrines which could not be reasonably applied to speech of government employees, ${ }^{40}$ and by outlining the less stringent procedural requirements for restrictions on government employees' speech. ${ }^{41}$ This same line of reasoning generally applies to the greater authority public employers have in impinging upon public employees' associational claims.

Although it is generally agreed that the government has more power to interfere with constitutional rights in its employment capacity, ${ }^{42}$ it is far from clear how to assess which employment practices are permissible and which are not. ${ }^{43}$ In order to get to the bottom of this thorny question,

agency's effective operation, the government employer must have some power to restrain her.

See also Tushnet, supra note 34 , at 1250 ("The government has instrumental or programmatic goals within the domain of management. When acting there, it may restrict individual autonomy in the service of its programmatic goals") (citing C. Edwin Baker, Campaign Expenditures and Free Speech, 33 Harv. C.R.-C.L. L. Rev. I, 16-2 I (1998)). Indeed, absent contractual, statutory or constitutional restriction, the government is entitled to terminate employees and contractors on an at-will basis, for good reason, bad reason, no reason at all. See Umbehr, $5_{18} 8$ U.S. at 674 .

39 Arnett v. Kennedy, 416 U.S. I34, 168 (1974) (Powell, J., concurring). If it were otherwise, Justice Powell explains, the government employer would not be able to remove inefficient and unsatisfactory workers quickly and the government's substantial interest in so doing would be frustrated without adequate justification. See id.

40 See Waters, $5_{1}$ I U.S. at 672 (plurality opinion) (reviewing a number of First Amendment doctrines that do not apply with the same force in the government as employer context, including instances in which the employer "may bar its employees from using Mr. Cohen's offensive utterance to members of the public or to the people with whom they work") (citing Cohen v. California, 403 U.S. 15, 24-25 (1971)).

41 See id. at 673 (observing that although speech restrictions on private citizens must precisely define the speech they target, a government employer is permitted to prohibit its employees from acting "rude to customers," even though this restriction would be void for vagueness under traditional First Amendment jurisprudence); see also Volokh, supra note 35, at $1494-97$.

42 See Waters, 5 I I U.S. at 673 (observing that the Court has "consistently given greater deference to government predictions of harm used to justify restriction of employee speech than to predictions of harm used to justify restrictions on the speech of the public at large").

43 See Rutan v. Republican Party of Ill., 497 U.S. 62, 95 (I990) (Scalia, J., dissenting); see also Connick v. Myers, 46I U.S. 138, 150 (1983) (noting the difficulty associated with the Pickering balancing); Volokh, supra note 35, at 1495-97 (describing the test implemented by Connick/Pickering as sub-strict scrutiny); Mark A. Lemley \& Eugene Volokh, Freedom of Speech and Injunctions in Intellectual Property Cases, 48 Duke L. J. 147, 204 ( I998) ("The Court has 
the Court has adopted two specific legal analytical frameworks for First Amendment association cases in the workplace: ${ }^{44}$ one for political affiliation cases and one for all other types of public employee associational claims.

\section{A. Public Employee Political Association Protections}

Notions of political discrimination in the public workplace derived initially from the Cold War era in a series of cases dealing with loyalty oaths. Loyalty oath cases derived from the fear of the spread of Communism after the Russian Revolution in 1917. During this time and thereafter, many laws were passed in the United States which sought to limit the ability of Communists or Communist sympathizers from gaining government employment and undermining the government. ${ }^{45}$ In particular, numerous federal and state laws were passed prohibiting the holding of public employment by those who refused to swear that they had not had any connection with the Communist Party ${ }^{46}$ It was therefore inevitable that during the height of the Cold War with the Soviet Union in the 1950s that the doctrine of unconstitutional conditions would find vitality in the freedom of association in the workplace cases. ${ }^{47}$

In these cases, the Court held that government workers were constitutionally protected from losing their jobs for refusing to take an oath or for refusing to sign a declaration about their political affiliation. ${ }^{48}$ For instance in Wieman $v$. Updegraff, ${ }^{49}$ the Supreme Court held that government workers were constitutionally protected from losing their jobs for not

acknowledged that 'such particularized balancing is difficult,' and this seems to be an understatement. From all we've seen of the lower court decisions, the test is essentially indeterminate in all but the easiest cases.") (quoting Connick, 46I U.S. at 150 ).

44 Intimate association claims discussed in Part II primarily revolve around personal decisions pertaining to sexual matters outside of the workplace. See infra notes $81-105$ and accompanying text.

45 For example, the Feinberg Law, passed by the State of New York, provided for, inter alia, removal from academic public employment for "the utterance of any treasonable or seditious word ... or the doing of any treasonable or seditious act." See Keyishian v. Bd. of Regents, 385 U.S. 589, 593 ( 1967 ) (citing N.Y. Education Law § 302 I (McKinney 1953)).

46 See, e.g., Wieman v. Updegraff, 344 U.S. $183,185 \&$ n. I (1952) (setting forth the provisions of such a loyalty oath for public employees in the State of Oklahoma).

47 Being labeled a Communist during the McCarthy Era was no small matter. See id. at 190-91 ("There can be no dispute about the consequences visited upon a person excluded from public employment on disloyalty grounds. In the view of the community, the stain is a deep one; indeed, it has become a badge of infamy. Especially is this so in time of cold war and hot emotions when "each man begins to eye his neighbor as a possible enemy" (quoting Judge Learned Hand, Address at the 86th Convocation of the University of the State of New York (October 24, 1952))).

48 See Bd. of County Comm'rs v. Umbehr, 5 I 8 U.S. 668, 674-75 ( 1996) (citing Wieman, 344 U.S. 183; Keyishian v. Bd. of Regents, 385 U.S. 589 ( 1967$)$ ).

49 Wieman v. Updegraff, 344 U.S. 183 (1952). 
swearing an oath regarding their past and present political affiliation. ${ }^{50}$ Similarly, eight years later in Shelton $v$. Tucker, ${ }^{51}$ the Court struck down an Arkansas statue which required, as a prerequisite for employment, public school teachers to file affidavits giving names and addresses of all organization to which they had belonged or contributed to within the preceding five years. ${ }^{52}$ Finally, Keyishian $v$. Board of Regents ${ }^{53}$ struck down a New York state law because of its overbreadth with regard to public employees' rights to freedom of association..$^{54}$

As loyalty oaths became less visible after the 1950 s and 1960 s, a second generation of unconstitutional conditions in association cases came to the legal forefront starting in the 1970s. Specifically, these cases dealt with the so-called "spoils system," or political patronage, ${ }^{55}$ which rewards public employment based on loyalty to a given political party. In Elrod v. Burns, ${ }^{56}$ for example, the plurality decision written by Justice Brennan found that Illinois public employees, who were non-confidential, nonpolicymaking employees, ${ }^{57}$ could not be fired merely because of their partisan political affiliation. ${ }^{58}$ In this regard, Brennan stated: "[P]atronage dismissals severely restrict political belief and association. Though there is a vital need for government efficiency and effectiveness, such dismissals are on balance not the least restrictive means for fostering that end." 59

Four years later, a majority of the court upheld the major premises of Elrod in Branti ข. Finkel. ${ }^{60}$ There, Justice Stevens, writing for the majority, similarly noted that assistant public defenders were nonconfidential, nonpolicymaking officials whose employment could not be terminated

50 See id. at 192 ("We need not pause to consider whether an abstract right to public employment exists. It is sufficient to say that constitutional protection does extend to the public servant whose exclusion pursuant to a statute is patently arbitrary or discriminatory").

5 I Shelton v. Tucker, 364 U.S. 479 (1960).

52 Id. at $485^{-86}$ ("It is not disputed that to compel a teacher to disclose every associational tie is to impair that teacher's right to free association, ... a right which, like free speech, lies at the foundation of a free society").

53 Keyishian v. Bd. of Regents, 385 U.S. 589 ( 1967 ).

54 Id. at 609 (striking down New York law as overbroad because it barred public "employment both for association which legitimately may be proscribed and for association which may not be proscribed consistent with First Amendment rights").

55 For a well-known literary portrayal of the political spoils system, see W. RIORdon, Plunkitt of Tammany Hall (Aifred A. Knopf, Inc. 1948).

56 Elrod v. Burns, 427 U.S. 347 (1976) (plurality opinion).

57 If a public employee is either confidential or a policymaker, there is a general agreement that public officials may rely on party affiliation in appointing these high level officials. See id. at 367 .

58 Id. at $372-73$.

59 Id. at 372.

60 Branti v. Finkel, 445 U.S. 507 (1980). 
solely based on their partisan political affiliation. ${ }^{61}$ Relying specifically upon the doctrine of unconstitutional conditions, the Court found that "[i]f the First Amendment protects a public employee from discharge on what he [says], it must also protect him from discharge on what he believes." 62 Moreover, Justice Stevens found that the facts of the case fell clearly within the holding of Perry $v$. Sindermann that the government "may not deny a benefit to a person on a basis that infringes his constitutionally protected interests." 63

More recently, in Rutanv. Republican Party of Illinois, ${ }^{64}$ the Supreme Court extended the holding of Elrod and Branti to other adverse employment decisions such as failures to hire, rehire, transfer, or promote. ${ }^{65}$ Writing for the Court once again, Justice Brennan found that the Illinois Governor's practice of limiting state employment and beneficial employment-related decisions to those who supported the Republican Party unconstitutionally impinged on Democrats' rights to association. ${ }^{66}$ Nevertheless, the Court emphasized that its holding applied only to non-policymaking employees and that a government employer is still permitted to terminate policymaking workers for their political beliefs. At these higher levels, government decisionmakers are allowed to politically discriminate to ensure loyalty to the governing party's political agenda.

In short, many public employees are provided substantial protection in the workplace for their political associations.

\section{B. Public Employee Workplace Association Protections}

Whereas the cases discussed in the previous section protect government workers in their political affiliations, public workers are protected more generally from termination for engaging in associational activity counter

61 Id. at 519-20.

$62 \mathrm{Id}$. at 515 .

63 Id. (quoting Perry v. Sindermann, 408 U.S. 593, 597 (1972)). Justice Stevens also applied a type of strict scrutiny analysis in this case. See id. at 515-16. "[U]nless the government can demonstrate 'an overriding interest,' . . .of vital importance,' requiring that a person's private beliefs conform to those of the hiring authority, his beliefs cannot be the sole basis for depriving him of continued public employment") (quoting Elrod v. Burns, 427 U.S. 347, 362, $368(1976)$ ).

64 Rutan v. Republican Party of Ill., 497 U.S. 62 (1990).

65 See id. at 74 .

66 See id. at 78 ("Under our sustained precedent, conditioning hiring decisions on political belief and association plainly constitutes an unconstitutional condition, unless the government has a vital interest in doing so"). The Court also rejected that notion that these types of employment decisions should somehow be treat differently because they did not have the same impact on individual's First Amendment rights as an ultimate firing decision. See id. at 73 (finding that "[e]mployees who find themselves in dead-end positions due to their political backgrounds are adversely affected") (emphasis in original). 
to their government employers' wishes. ${ }^{67}$ The government employer in these cases, for its part, seeks to protect legitimate business interests in running an efficient workplace. Consequently, the strict scrutiny analysis applied to government employer actions in the political association cases is inappropriate. Instead, the question is one of government "reasonableness" under all the circumstances and courts engage in a balancing of the relevant employer and employee interests. ${ }^{68}$

Although the public employee First Amendment framework was initially established for free speech/free expression cases, a similar analysis applies to freedom of association claims. ${ }^{69}$ For public employees to make out First Amendment retaliation claims based on their right to association, the reasonableness of the public employer response must go through at least a three-step analysis. ${ }^{70}$

67 See generally Paul M. Secunda, The (Neglected) Importance of Being Lawrence: The Constitutionalization of Public Employee Rights to Decisional Non-Interference in Private Affairs, 40 U.C. Davis L. Rev. 85, 95-105 (2006).

68 See Jonathan C. Medow, The First Amendment and the Secrecy State: Snepp v. United States, 130 U. PA. L. Rev. 775, 816 (1982) ("Implicit in Pickering seems to be a determination that 'reasonableness' is the standard by which to judge the conditioning of public sector employment on a relinquishment of some measure of first amendment rights").

69 See, e.g., Cobb v. Pozzi, 363 F.3d 89, 102 (2d Cir. 2004); Edwards v. City of Goldsboro, I 78 F.3d 231, 249 (4th Cir. 1999); Ross v. Clayton County., I73 F.3d 1305, I3Io (I Ith Cir. 1999).

70 There are two additional steps that may apply to the Pickering framework in the context of a public employee's associational claim. The Supreme Court gave the Pickering balancing test an important additional gloss in the speech case of Connick v. Myers, 46 I U.S. I 38 (1983). Connick requires that even before a Pickering balance can occur, a court had to consider as a threshold matter whether the public employee was speaking on "a matter of public concern." Id. at $15^{\circ}$. There is some dispute over whether an association claim must relate to a matter of public concern before the Pickering balance applies. See Shrum v. City of Coweta, Okla., 449 F.3d I I 32, I 38 n.3 ( 1 oth Cir. 2006) (not reaching the question but observing that "[f]ive Circuits have adopted the public concern requirement for freedom of association claims and two have not. See Hudson v. Craven, 403 F.3d 69I (9th Cir. 2005); Cobb, 363 F.3d at 102-03; Edwards, 178 F.3d at 249-50; Griffin v. Thomas, 929 F.2d I 210 , 1214 (7th Cir. 1991); Boals v. Gray, 775 F.2d 686 (6th Cir. 1985). But see Breaux v. City of Garland, 205 F.3d I 50 , 157 n. 12 (5th Cir. 2000); Hatcher v. Bd. of Pub. Educ. and Orphanage, 809 F.2d I 546, I $55^{8}$ ( I I th Cir. I987)"). The I t th Circuit recently reaffirmed its allegiance to the no public concern test faction. See Cook v. Gwinnett County School Dist., 414 F.3d I313 (I th Cir. 2005). Regardless, this difficult issue further supports the need for some unifying federal standard to decide these Pickering association cases.

It is also unclear whether the recent decision in Garcetti $v$. Ceballos applies to associational claims. 126 S. Ct. 1951, 1960 (2006) ("[W]hen public employees make statements pursuant to their official duties, the employees are not speaking as citizens for First Amendment purposes, and the Constitution does not insulate their communications from employer discipline"). But see D'Angelo v. School Bd. of Polk County, Fla., 497 F.3d I 203 at 12 I 2 ( I Ith Cir. 2007) (holding that Garcetti does apply to associational claim); Cindrich v. Fisher, No. 05-1348, 2007 WL 1576403, at *7 (W.D. Pa. May 31, 2007) (same). If it does, it would require that the associational activity be engaged in as a citizen, as opposed as an employee. D'Angelo 497 F.3d at 
First, if the employee can show that he or she is engaged in protected associational activities, a court undertakes the Pickering balance of interests. Under this balancing test, first developed in the public school teacher case of Pickering $v$. Board of Education, ${ }^{71}$ a court weighs the First Amendment interests of the employee as a citizen against the government interest in running an efficient government service for the public. ${ }^{72}$ Here, much emphasis is placed on whether the employee's association causes a substantial disruption in the workplace. ${ }^{73}$ Substantial disruption, in turn, is measured based on "the impact of the [conduct] on working relationships, the harm caused by the [conduct], the public's interest in the [conduct], and the employee's relationship to that issue."74 Paradoxically, this substantial disruption standard appears to make most vulnerable those associations which are the most unpopular and warrant the most protection under the First Amendment. ${ }^{75}$ If the balance under Pickering favors the government, the public employee has no First Amendment rights in association.

Second, if the Pickering balance favors the employee, the employee is then considered to have engaged in protected activity. Next, under the evidentiary framework established in Mount Healthy City School District v. Doyle, ${ }^{76}$ the plaintiff must prove by a preponderance of the evidence that engaging in the protected activity was a substantial or motivating factor in the adverse employment action that the employee suffered. ${ }^{77}$ This showing may be based on both direct and circumstantial evidence that the most likely reason the employee lost their job, was demoted, etc., was because of the employee's associational activities.

Third, and finally, if the employee shows that the protected activity was a substantial or motivating factor for the adverse employment decision, the Government then has the burden of persuasion to show that it would have made the same decision even in the absence of the protected conduct. ${ }^{78}$ If the public employer is successful in meeting this burden, there is again no liability. This is because "[t]he constitutional principle at stake is

1213. The 1 ith Circuit concluded that Garcetti does apply to associational claims and requires that a public employee not be acting as an employee pursuant to official duties in order to have a First Amendment associational claim. Id. at 1213 . This appears to be the first decision on the issue and therefore, it remains to be seen whether other courts follow the I Ith Circuit lead. Needless to say, the arrival of Garcetti further complicates this area of law.

7 I Pickering v. Bd. of Educ., 391 U.S. 563, 568 (1968).

72 Id. at 57 I-72. (2005).

73 Randy J. Kozel, Reconceptualizing Public Employee Speech, 99 Nw. U. L. Rev. I007, 1018

74 Charles W. Rhodes, Public Employee Speech Rights Fall Prey to an Emerging Doctrinal Formalism, I5 WM. \& MARY BILL RTs. J. I I 73, 1177 (2007).

75 Kozel, supra note 73, at 1018.

76 Mount Healthy City Sch. Dist. v. Doyle, 429 U.S. 274 (1977).

77 Id. at 287.

$78 \mathrm{Id}$. 
sufficiently vindicated if such an employee is placed in no worse a position than if he had not engaged in the conduct." 79 Only if the employee can survive this third and last obstacle may liability be imposed.$^{80}$

This complicated framework highlights the difficulties public employees have when they maintain that they were terminated from employment for engaging in protected, associational activities. Nevertheless, these types of associational rights are more secure then the developing rights to intimate association described below.

\section{The Right to Intimate Association in the Workplace ConteXt}

Since Brandeis and Warren wrote their famous article in 1890 about privacy rights, ${ }^{81}$ the only thing that commentators have seemed to agree on concerning the right to privacy is that there is very little agreement about its contours. ${ }^{82}$ But privacy rights developed under the substantive due process component of the liberty interest in the Due Process Clause of the Fifth and Fourteenth Amendment ${ }^{83}$ also overlap with the right to association. More specifically, the Supreme Court in Roberts $v$. United States Jaycees $^{84}$ recognized a right to intimate association. ${ }^{85}$ The Roberts Court defined the right to intimate association as the ability to form and maintain human bonds unmolested by the State, concluding that, "[p]rotecting these [intimate] relationships from unwarranted state interference ... safeguards the ability independently to define one's identity that is central to any concept of liberty." ${ }^{86}$ In short, the right of intimate association involves the

79 Id. at $285-86$.

80 But even then, plaintiff-employees must deal with the intricacies of liability under the federal civil rights statute, Section I 983,42 U.S.C. $\$ 1983$, and various sovereign immunity doctrines. See, e.g., Harlow v. Fitzgerald, 457 U.S. 800, 818 (1982) ("[G]overnment officials performing discretionary functions, generally are shielded from liability for civil damages insofar as their conduct does not violate clearly established statutory or constitutional rights of which a reasonable person would have known"). Questions regarding damages under Section 1983 and sovereign immunity are beyond the scope of this article.

8I See Samuel Warren \& Louis Brandeis, The Right to Privacy, 4 Harv. L. Rev. 193 (I 890).

82 See Daniel J. Solove, Conceptualizing Privacy, 90 CaL. L. Rev. 1087, I099-124 (2002) (cataloging in depth the different conceptions of privacy that various courts and commentators have championed).

83 See Roe v. Wade, 410 U.S. $113,152-53$ (1973) (in the abortion context, locating a woman's right to choose whether to terminate her pregnancy within the liberty interest contained in the substantive component of the due process clause of the Fifth and Fourteenth Amendments); Griswold v. Conn., 381 U.S. 479, 485 (1965) (in a contraception case, finding that "[ $t$ ] he present case ... concerns a relationship lying within the zone of privacy created by several fundamental constitutional guarantees").

84 Roberts v. U.S. Jaycees, 468 U.S. 609 (1984).

85 Id. at 618-19.

$86 I d$. at 619. 
ability to engage in human relationships of all types. ${ }^{87}$

More recently, the parameters of that associational privacy right have been expanded by the United States Supreme Court's decision in Lawrence v. Texas. ${ }^{88}$ Prior to Lawrence, significant Supreme Court cases, such as Bowers $v$. Hardwick, ${ }^{89}$ appeared to discount the importance of such human relationships. Bowers had held that there was no constitutional right to engage in homosexual sodomy. ${ }^{90}$

In overturning Bowers, Lawrence's central holding was that the Texas sodomy statute at issue furthered no legitimate state interest which could justify the intrusion into the personal and private life of the individual. ${ }^{91}$ The most important constitutional innovation wrought by this holding is the apparent attachment of some form of heightened scrutiny to the right to be free from decisional interference in matters of an intimate nature. ${ }^{92}$ Indeed, implicit in this holding is the need to balance individual privacy interests against legitimate and substantial state interests. ${ }^{93}$

Utilizing the Pickering framework for these types of intimate associational claims in the workplace, ${ }^{94}$ I have developed a new framework for balancing the employee's right as citizen to be free from unwanted and unjustified governmental intrusions in the employee's personal and private life against the government's interest as employer to run an efficient governmental service for the benefit of the public. ${ }^{95}$ At times, this balance will obviously be strongly in favor of either the government or the employee, depending on whether the employee's off-duty, private conduct has any impact on the employer. If there is no impact, there is no "work-relatedness," 96 and the

87 See Solove, supra note 82 , at $112 \mathrm{I}$. This conception of privacy "attempts to define what aspects of life we should be able to restrict access to, or what information we should be able to control or keep secret." Id.

88 Lawrence v. Texas, 539 U.S. $55^{8}(2003)$.

89 Bowers v. Hardwick, 478 U.S. 186 (1986).

90 Id. at 190.

91 See Lavrence, 539 U.S. at 578.

92 See Secunda, The (Neglected) Importance of Being Lawrence, supra note 67, at 89.

93 See Paul M. Secunda, Lawrence's Quintessential Millian Moment and its Impact on the Doctrine of Unconstitutional Conditions, 50 VILL. L. Rev. 117,138 \& n.98 (2005) (citing Dale Carpenter, Symposium: Gay Rights After Lawencev. Texas, Is Lawrence Libertarian?, 88 MinN. L. Rev. 1140,1151 (2004)).

94 I refer to this right of intimate association in previous pieces as the right to "decisional non-interference in private affairs," borrowing Solove's formulation. See Secunda, The (Neglected) Importance of Being Lawrence, supra note 67, at 89 \& n. 14 (citing Daniel J. Solove, $A$ Taxonomy of Privacy, 154 U. PA. L. REv. 477, 49 I (2006)). claims).

$95 \mathrm{Id}$. at 122-124 (describing the modified Pickering analysis for intimate association

96 See Cynthia L. Estlund, Free Speech Rights That Work at Work: From the First Amendment to Due Process, 54 UCLA L. Rev. 1463, 1468 (2007) ("While that outer limit is a bit further from the workplace than one might have expected, at some point along the spectrum of work-relatedness, the public employee apparently escapes the Connick-Pickering niche and recovers 
employee's interests will generally prevail.

For more intricate intimate association cases, it is helpful to consider the "nexus test" used for employee discharges by labor arbitrators in the union environment. ${ }^{97}$ The general principle is that an employer should not be able to interfere with an employee's life outside of work unless there is more than a de minimis adverse impact on the employer's work place. ${ }^{98}$ This impact can be measured based on the detriment to the employer's public image, the inability of the worker to interact with his or her co-employees, or the simple inability of the employee to carry out the essential functions of his or her position as a result of the private conduct. ${ }^{99}$ But outside of these types of legitimate and substantial justifications for interference in an employee's private life, a government employer should be constrained by the liberty interest contained in the substantive component of the Due Process Clause of the Fifth and Fourteenth Amendments from interfering with the rights of intimate association of their employees.

Although this intimate association right has not been widely utilized by courts in the United States, there are some encouraging signs. In a recent state court case from North Carolina, a female sheriff dispatcher, Debora Hobbs, was told by her supervising sheriff, Carson Smith, to marry her live-in boyfriend, move out, or lose her job. ${ }^{100}$ The sheriff based his actions on a state anti-cohabitation statute from 1805 and, in fact, the female dispatcher lost her position when she refused to comply. ${ }^{101}$ The dispatcher sued and won based on the court finding, in light of Lawrence v. Texas, ${ }^{102}$ that her firing unconstitutionally infringed her liberty interests under the Due Process Clause of the Fourteenth Amendment. ${ }^{103}$ Although

her freedom as a citizen vis-à-vis the government").

97 See Paul M. Secunda, Getting to the Nexus of the Matter: A Sliding Scale Approach to Faculty-Student Consensual Relationship Policies in Higher Education, 55 SyRacuse L. REv. 55, 68-73 (2004).

98 See id. at 69; see also Kozel, supra note 73, at 105 I (noting that the Supreme Court has made a distinction in public employee speech cases based on whether the speech or expression in question included any indicia of the speaker's employment).

99 See Secunda, Getting to the Nexus of the Matter, supra note 97, at 70 (citing W.E. Caldwell Co., 28 Lab. Arb. Rep. (BNA) 434, 436-37 (1957) (Kesselman, Arb.)).

100 See Steve Hartsoe, ACLU Challenges N.C. Cohabitation Law, WASH. Post, May 10, 2005 , at Ao6.

101 See Secunda, The (Neglected) Importance of Being Lawrence, supra note 67 , at I $_{3}$ I-32 (citing Hartsoe, supra note IOo).

102 Lawrence v. Texas, 539 U.S. $55^{8}$ (2003).

103 See Hobbs v. Smith, No. 05 CVS 267, 2006 WL 3103008, at *I (N.C. Super. Ct., Aug. 25, 2006); see also Andrea Weigl, Judge Rules Against Cohabitation Law, THE News \& ObSERver (Raleigh, N.C.), July 2 I, 2006, at A I, available at http://www.newsobserver.com/ I02/ story/462833.html (last visited Nov. 5, 2007); Posting of Paul M. Secunda, North Carolina Cohabitation Law Struck Down in Case of Female Sheriff Dispatcher, Workplace Prof Blog, to http://lawprofessors.typepad.com/laborprof_blog/2006/o7/north_carolina_.html (July 2 I, 2006). 
the court's exact reasoning does not appear to have been published, ${ }^{104}$ the strongest argument to support its holding is that a public employer must have a substantial and legitimate interest before interfering with an employee's right to intimate association. ${ }^{105}$

So, in addition to the more generic right to association found within the First Amendment of the U.S. Constitution, there are additional sources of associational protections found under Fifth and Fourteenth Amendment substantive due process. In other words, there is a further layer of analysis for both public employers to think about when making workplace decisions potentially unrelated to the workplace and for employees to consider when shielding themselves from their public employer's overreaching.

Yet, there is a further complication caused by the recent development of an aggressive expansion of expressive association rights for organizations, including public and private employers. It is that subject that this article now considers in its various dimensions.

\section{The Right to Expressive Association IN THE EMPLOYMENT CONTEXT}

The landmark case of Roberts $v$. United States Jaycees, ${ }^{106}$ not only introduced the conception of intimate association, but it broke new ground in freedom of association cases by introducing an instructive dichotomy. In Roberts, Justice Brennan divided all previous constitutional association cases into two categories. On the one hand, the right to intimate association, which concerns rights to personal liberty located within the Due Process Clause of the Fourteenth Amendment. ${ }^{107}$ On the other hand, the right to expressive association, which involves association for the promotion of rights found primarily within the First Amendment. ${ }^{108}$ The nature and degree of constitutional protection depends for what purpose the organization engages in associational activities. ${ }^{109}$

In Roberts, the state interference at issue involved the application of Minnesota's state public accommodations statute's gender discrimination provisions to the membership policies of the Jaycees, which did not grant

104 See Judge Rules N.C. Anti-Cohabitation Law Unconstitutional, USA Today (July 2 I, 2006), available at http://www.usatoday.com/news/nation/2006-07-21-cohabitation_x.htm ("State Superior Court Judge Benjamin Alford issued the ruling late Wednesday, saying the law violated Hobbs' constitutional right to liberty. He cited the 2003 U.S. Supreme Court case titled Lawrence $v$. Texas, which struck down a Texas sodomy law").

105 See Secunda, The (Neglected) Importance of Being Lawrence, supra note 67, at 16.

I06 Roberts v. U.S. Jaycees, 468 U.S. 609 (1984).

107 Id. at 617-18.

$108 \mathrm{Id}$. at 618 .

109 Id. 
women full membership in their organization. ${ }^{110}$ The Court first explained that the Jaycees was not an intimate association because of its size, lack of selectivity in defining group membership, and its generally open, public nature. ${ }^{111}$ Having eliminated intimate association from consideration, the Court recognized the Jaycees as a type of expressive association whose members affiliated with one another to advocate certain views. ${ }^{112}$

In this regard, the Court stated, "we have long understood as implicit in the right to engage in activities protected by the First Amendment a corresponding right to associate with others in pursuit of a wide variety of political, social, economic, educational, religious, and cultural ends." 113 The Court went on to conclude that "[i]n view of the various protected activities in which the Jaycees engages ... that right is plainly implicated in this case." 114 Jaycees' activities are described later in the opinion as taking public positions on a number of diverse issues and regularly engaging "in a variety of civic, charitable, lobbying, fundraising, and other activities worthy of constitutional protection under the First Amendment." 15

Some sixteen years later, a newly constituted Supreme Court had the opportunity to develop further the expressive association doctrine in the form of Boy Scouts of America v. Dale, ${ }^{116}$ in which the Court found in favor of

I Io Id. at 612-17.

I I Id. at 620-2 I. Not surprisingly, the Court also found employers do not have rights of intimate association when selecting employees. See id. at 620 ("[T]he Constitution undoubtedly imposes constraints on the State's power to control the selection of one's spouse that would not apply to regulations affecting the choice of one's fellow employees").

$112 I d$. at 622. Even though the Court concluded that the Jaycees had expressive association rights and those rights were significantly burdened by the application of the public accommodation statute, the Court nevertheless held that the State's compelling interest in eradicating gender discrimination justified the infringement on the group's rights. Id at $622-23$.

113 Id. at 622.

I 4 Id.

I 15 Id. at 626-27. Contrary to Justice Brennan's dichotomy, Justice O'Connor's concurrence in Roberts suggests that non-intimate association cases should be further broken down into expressive association and commercial association cases to accord sufficient protection to expressive associations, while at the same time placing appropriate burdens on groups claiming the protection of the First Amendment for commercial association purposes. Id. at 632 (O'Connor, J., concurring). Whereas those associations that were predominantly expressive were due substantial protection from governmental interference, O'Connor argued that commercial associations were largely non-expressive and, therefore, state regulation was permissible as long as it was rationally related to a legitimate government purpose. Id. at 633-35. Nevertheless, O'Connor does recognize that "[m]any associations cannot readily be described as purely expressive or purely commercial" and that "[t]he standard for deciding just how much of an association's involvement in commercial activity is enough to suspend the association's First Amendment right to control its membership cannot ... be articulated with simple precision." Id. at 635 .

I 16 Boy Scouts of America v. Dale, 530 U.S. 640 (2000). 
the Boy Scouts' expressive association claims. ${ }^{117}$ In an opinion written by Chief Justice Rehnquist, the Court held that the New Jersey state public accommodations statute impermissibly infringed on the. Scouts' expressive association rights by requiring them to have a gay assistant scoutmaster as a member. ${ }^{118}$

The Court began its analysis by asking whether the Boy Scouts engaged in expressive activity, cautioning that "a group must engage in some form of expression, whether it be public or private."119 The Court then examined the record, including the Boy Scouts' mission statement, and concluded that its mission was "to instill values in young people," including the values of being "morally straight" and "clean." 120 Based on this mission, the Court concluded that, "[i]t seems indisputable that an association that seeks to transmit such a system of values engages in expressive activity." 121

The Court then deferred to the group's description of both its message concerning being anti-homosexual and its belief that having a gay assistant scoutmaster would substantially impair its message of living a "morally straight" and "clean" life. ${ }^{122}$ Finally, given the severity of the intrusion into the Scouts' rights to expressive association, the Court held that their First Amendment rights prevailed. ${ }^{123}$

Although neither Dale nor Roberts involved employers asserting expressive association rights, previous Supreme Court cases make it clear that employers, both public and private, have expressive association rights. This conclusion is based on an earlier right-to-association opinion in Hishon $v$. King \& Spalding, ${ }^{124}$ which concerned an allegedly unlawful gender discriminatory law firm partnership decision under the federal employment discrimination law, Title VII of the Civil Rights Act of $1964 .{ }^{125}$ One of the law firm's arguments was that requiring them to take an employee into partnership would interfere with the law firm's rights to association. ${ }^{126}$ In other words, the law firm should not be forced to take into membership those partners it did not want.

The Court, however, rejected this argument. Finding that the law firm

I 7 Id. at 659 .

118 Id. at $656-59$.

I 19 Id. at 648 .

120 See id. at 648-50. But see id. at 675 (Stevens, J., dissenting) ("Beyond the single sentence in these policy statements, there is no indication of any shared goal of teaching that homosexuality is incompatible with being 'morally straight' and 'clean").

I 2 I See id. at 650 (citing Roberts v. U.S. Jaycees, 468 U.S. 609, 636 (1984) (O'Connor, J., concurring)).

122 See id. at $65 \mathrm{I}-53$.

123 See id. at 657-59.

124 Hishon v. King \& Spalding, 467 U.S. 69 (1984).

12542 U.S.C. $\$ \S 2000 e-17$ (2000).

I 26 Hishon, 467 U.S. at 78. 
only had a right to association consistent with the "distinctive contribution ... to the ideas and beliefs of our society" that lawyers make through their activities, ${ }^{127}$ the Court could not see how considering the female partnership candidate on her merits as opposed to her sex would interfere with these association rights. ${ }^{128}$ Hishon thus appears to stand for two propositions when it comes to expressive association claims by employers: (1) under appropriate circumstances, such rights may exist, and (2) the employer conduct in question has to be somehow connected to the expressive purpose of the organization. The law firm failed under the second prong in Hishon because being female had nothing to do with the ability to adhere to and propagate the ideas and beliefs of the firm.

Although there have not yet been many cases in which employers have sought to overcome countervailing employee civil liberties or civil rights through use of expressive association claims, there is some indication that more cases may be on the way. In a brief filed in the Title VII case of Curay-Cramer v. Ursuline Academy of Wilmington, ${ }^{129}$ a Catholic school argued that as an expressive association it should not be required to maintain in employment a teacher who signed a pro-choice advertisement in the local newspaper. ${ }^{130}$ The Third Circuit's decision in Curay-Cramer, however, found for the school on other grounds and did not address the expressive association argument. ${ }^{131}$ There has also been recent academic commentary on the issue, supporting the idea that religiously oriented private employers should be able to use such rights to overcome contrary antidiscrimination laws. ${ }^{132}$

The recognition of expressive association rights for employers would entail a vast accretion of employer power to potentially exclude unpopular, controversial, or just plain disagreeable employees from the workplace. Expressive association rights not only undermine employee's rights of association, which must be necessarily diminished by the recognition of a similar right for employers, but also such "liberty" rights are counter to antidiscrimination laws which push the "equality" rights of employees. And unlike the association rights discussed under Pickering previously, ${ }^{133}$ this constitutional right is not limited to the public sector and therefore,

127 Id. (citing NAACP v. Button, 37 I.S. 415, 43 I (1963)).

128 Id.

129 Curay-Cramer v. Ursuline Acad. of Wilmington, 450 F.3d I 30 (3d Cir. 2006).

130 See id.; Brief of Appellees the Ursuline Academy of Wilmington, 2005 WL 4906I 87 (Mar. 24, 2005), at 35-39.

13 I See Curay-Cramer, 450 F.3d at 142.

132 See Julie Manning Magid \& Jamie Darin Prenkert, The Religious and Associational Freedoms of Business Owoners, 7 U. PA. J. LAB. \& EMP. L. I9I, I92-93 (2005) (arguing that recent free exercise, hybrid rights, and associational cases decided by the Supreme Court support religiously devoted employers' rights to promote religion and disassociate from individuals who do not share their beliefs without violating antidiscrimination laws).

133 See supra notes $67-80$ and accompanying text. 
could have a much larger impact on the right to association in the American workplace.

Because of this developing state of affairs, I have offered in a previous piece an alternative vision which denies public employers constitutional rights to association, but would permit public employer interests to be recognized under the existing Pickering framework. ${ }^{134}$ In other words, the governmental interests recognized in Pickering are not in any sense constitutional rights, but rather recognition of the interests a government employer has in maintaining "a significant degree of control over their employees' words and actions" because "without it, there would be little chance for the efficient provision of public services." 135 The balance undertaken in Pickering is required because even though the government employer performs "important public functions," 136 and consequently possesses far broader powers in its employer capacity than in its sovereign capacity; ${ }^{137}$ nevertheless, "a citizen who works for the government is nonetheless a citizen." 138

Similarly, the interests that public employers have in conveying and advocating certain views and maintaining the core values of their institutions may be seen as more akin to Pickering efficiency interests than a First Amendment right to expressive association. ${ }^{139}$ As the Garcetti Court observed: "Supervisors must ensure that their employees' official communications are accurate, demonstrate sound judgment, and promote the employer's mission." 140 In setting out the relevant interests, the Court utilizes the language of efficiency interests, not of employer expressive association rights. ${ }^{141}$

134 See generally Paul M. Secunda, The Solomon Amendment, Expressive Associations, and Public Employment, 54 UCLA L. Rev. 1767 (2007). Of course, private employers, like the law firm in Hishon, would not come under Pickering because of the lack of state action. See supra note 3 and accompanying text. To the extent that private employers have been found to have expressive association rights, those rights might be impermissibly burdened by application of a statutory scheme like Title VII. See Magid \& Prenkert, supra note 132, at 192-93. This is yet another layer of complexity to add to the burgeoning varieties of rights to association claims in the workplace.

I 35 Garcetti v. Ceballos, 126 S. Ct. I95I, 1958 (2006) (citing Connick v. Myers, 46 I U.S. $138,143(2003))$.

I 36 See id. at 1959 (citing Rankin v. McPherson, 483 U.S. 378,384 (1987)).

137 See supra note 33-4I and accompanying text.

138 See Garcetti, $126 \mathrm{~S}$. Ct. at 1958.

I39 See id. at 1960 ("Employers have heightened interests in controlling speech made by an employee in his or her professional capacity. Official communications have official consequences, creating a need for substantive consistency and clarity").

I40 Id. (emphasis added).

I4I The absence of Dale and Roberts from the Garcetti opinion is particularly telling. One would expect that if public employers were thought to have expressive association rights the Court would have explored that issue in Garcetti. See Secunda, The Solomon Amendment, supra note 134 , at 1809 . 
Based on this governmental interests analysis, if a public employer wishes not to hire a prospective employee because that employee has engaged in controversial associations, intimate or otherwise, the proper analysis is not to suggest that the government has a constitutional right as an expressive association to disassociate itself from those individuals it deems are promoting antithetical messages. Rather, a court should determine whether the constitutional rights of the individual cannot be recognized without substantially disrupting the public employer's enterprise. ${ }^{142}$ This proposed analysis is more consistent with constitutional doctrine in the public employer area and does not take the unprecedented step of suggesting that government employers have First Amendment rights. ${ }^{143}$

But whether my expressive association analysis or intimate association analysis is adopted by courts one day or not, this article thus far has hopefully accomplished one overarching goal: to establish that the freedom of association just in its constitutional dimensions, not even to mention its statutory and common law incarnations, is a hopeless array of confusing, contradictory, and just plan dumbfounding legal doctrine. It is time to consider alternatives. Congress through its interstate commerce power has just the ability to bring some semblance of order to this jurisprudential mess.

\section{Proposal: The Federal Freedom of Association IN THE WORKPLACE ACT}

The proposal made in this Part stems from the idea that it would be better in this area of the law if courts could avoid deciding tricky freedom of association constitutional doctrine and instead ground their decisions on appropriate statutory grounds. ${ }^{144}$ Although there is currently no universal freedom of association in the workplace legislation, ${ }^{145}$ Congress is well

142 I do not mean to suggest that the Pickering balance does not have its own shortcomings. Its reliance on determining constitutional rights based on whether a public employee's conduct causes his or her employer substantial disruption is close to approaching the constitutionalization of the heckler's veto. See Kozel, supra note 73, at 1018 ("Such a test is inconsistent with the notion of robust exchange of divergent ideas, as it leaves vulnerable the speech that is most likely to have a strong effect").

143 The most persuasive argument against finding that public employers have expressive association rights is a structural one. It is simply this: the Bill of Rights is about protecting the rights of the governed, not the governing. See Broad. Sys., Inc. v. Democratic Nat'l Comm., 412 U.S. 94, 139 (1973) (Stewart, J., concurring) ("The First Amendment protects the press from governmental interference; it confers no analogous protection on the Government").

144 Lowe v. S.E.C., 472 U.S. I8I, I90 (1985) ("[W]e should 'not decide a constitutional question if there is some other ground upon which to dispose of the case'") (quoting Escambia County, Florida v. McMillan, 466 U.S. 48, 5 I ( 1984 ) (per curiam)); see also Atkins v. Parker, 472 U.S. I 1 5, 123 (1985); Ashwander v. TVA, 297 U.S. 288, 347 (1936) (Brandeis, J., concurring).

145 For instance, Section 7 of the National Labor Relations Act only applies to private employers and does not concern associational activities of workers that are not labor-oriented. 
within its commerce clause power ${ }^{146}$ to enact such minimum-conditionsin-the-workplace legislation as long as the provisions do not otherwise violate the Constitution. ${ }^{147}$

Congress should be able to protect workers from being harassed and intimidated by employers from exercising their associational rights as a minimal working condition. Or put differently, Congress should be able to enact laws that prohibit employers from firing workers who refuse to give up their desired associations at their employer's request. It is also clear that Congress has employed this legislative power to bar illicit causes for discharge under federal anti-discrimination law. ${ }^{148}$

Using this power, and after making the necessary jurisdictional finding that, "the existence in industries affecting commerce, of arbitrary infringement of employees' rights to association, burdens commerce and the free flow of goods in commerce," 149 such a federal statute would simply state: "All employees are guaranteed freedom of association inside and outside the workplace, unless the employer can demonstrate legitimate and substantial business reasons for impinging on such employee freedoms."

This proposed bill, the Freedom of Association in the Workplace Act (FAWA), would be jurisdictionally sound and would codify a version of the Pickering analysis for all forms of employee claims to associational rights. By using the word "substantial" as far as the employer's burden in overcoming the employee's associational rights, Congress would be placing its thumb intentionally on the employee's side of the balance and going beyond what the Constitution requires so that such fundamental rights could not be impinged upon based on de minimis workplace disruption grounds. Consistent with Title VII, the word "demonstrate," as far as the employer's burden in these cases, would mean "meets the burdens of production and

See Eastex Inc. v. N.L.R.B., 437 U.S. 556, 567-68 (1978) (limiting protected conduct under section 7 to concerted activity that bears a "relationship to employees' interests as employees").

146 In addition, the Commerce Clause, U.S. ConsT. art. I, $\$ 8$ ("The Congress shall have Power ... To regulate Commerce with foreign nations, and among the several States, and with the Indian Tribes"), has been interpreted to give Congress an almost limitless right to legislate in the labor relations area. Brown v. Hotel \& Rest. Employees Int'l Union Local 54, 468 U.S. 491, 50 I (1984); N.L.R.B. v. Jones \& Laughlin Steel Corp., 30I U.S. I ( 1937); see also Howell Chevrolet Co. v. N.L.R.B., 346 U.S. 482 (1953) (upholding application of NLRA to small local retailers of automobiles).

147 Contrary state laws would not be an issue as a result of the operation of the Supremacy Clause of Article VI of the U.S. Constitution. U.S. ConsT. art. VI ("This Constitution, and the Laws of the United States which shall be made in Pursuance thereof ... shall be the supreme Law of the Land").

I48 See, e.g., Title VII of the Civil Rights Act of 1964, 42 U.S.C. $\$ \S 2000 e-17$ (2000); Americans with Disabilities Act, 42 U.S.C. $\$ \S 12101-12213$ (2000); Age Discrimination in Employment Act, 29 U.S.C. \$\$ $62 \mathrm{I}-34$ (2000).

149 This jurisdictional language is based on that found in the Age Discrimination in Employment Act, 29 U.S.C. $\$ 62$ I (a)(4) (2000). 
persuasion." 150

FAWA would staunch the current harms being caused to both employees and employers by the current freedom of association legal scheme. Employees would no longer suffer because the scope of their associational rights hinge on irrelevant factors, such as the public or unionized nature of their workplace. At the same time, employers, especially public employers, would not need to be constantly vigilant that some form of associational right of their employees is being implicated by their workplace decisions. ${ }^{151}$ They instead can gain the desired predictability once they become familiar with the parameters of the new law. ${ }^{152}$

The proposed legislation would also have advantages over existing statutory frameworks that protect associational rights to more limited degrees. The proposed federal bill would apply to public workers and would extend the associational protections to all types of membership organizations and associational activities, not just to formation of unions or other labor-related activities. ${ }^{153}$ Unlike a number of recently enacted state laws that protect legal, off-duty conduct of employees, ${ }^{154}$ FAWA would have all the benefits that come with being a uniform federal law that applies in the same manner in all fifty states. ${ }^{155}$

Two further provisions would fill out the contours of this new legislation. Because there is already a well-defined scope of associational protection under existing constitutional law, the proposed legislation should also contain a provision stating: "Nothing in this Act shall be construed to apply a lesser standard than the standards applied currently to rights of association under the U.S. Constitution." 156 Nonetheless, an additional provision

15042 U.S.C. $\$ 2000 e(m)(2000)$.

I5I Jeffrey M. Hirsch, The Law of Termination: Regulatory Pragmatism in the Workplace (Nov. 26, 2007), available at http://ssrn.com/abstract $=1032667$ ("[Workplace] laws create a significant burden, as employers must determine which of these often complicated rules apply and how to satisfy the ones that do").

152 To the extent that the new law has some interpretative problems, Congress can always go back and amend the law to respond to whatever issues arise. It is certainly easier to change legal principles when they derive from statutory law rather than from constitutional law.

I53 So the proposed bill would provide more associational protection than section 7 of the National Labor Relations Act. See supra note 144 and accompanying text.

154 States with broad off-duty conduct statutes currently include Colorado, North Dakota, California, and New York. See Colo. Rev. Stat. \$ 24-34-402.5( I) (2007); N.D. Cent.

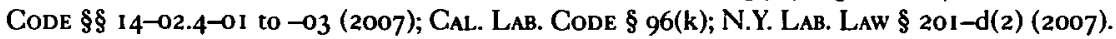
Additionally, a Connecticut statute protects employees, both on-duty and off-duty, from suffering adverse employment consequences for engaging in First Amendment-type activities. See Conn. Gen. Stat. AnN. § 31-5Iq (2007).

155 Hirsch, supra note 151 ("In the past, relying on state and local regulation of the workplace made sense. However, the lack of vertical integration makes far less sense in the modern economy. Many employers are at least regional, if not national, in scope").

I56 This language is based on similar language in the Americans with Disabilities Act 
would make clear that federal, state, and local decisionmakers are free to go beyond the floor of FAWA and provide additional associational protections if they so wish: "Nothing in this Act shall be construed to invalidate or limit the remedies, rights, and procedures of any Federal law or law of any State or political subdivision of any State or jurisdiction that provides greater or equal protection for the associational rights of employees that are afforded by this Act." 157

\section{Conclusion}

It is time to rethink how the United States enforces the right of association in the workplace. The proliferation of political associational rights, workplace associational rights, intimate association rights, and expressive association rights in the constitutional sphere over the last thirty years has made the scope of this fundamental civil liberty confusing and hard to enforce. Outside of the constitutional framework, which generally applies only to public employees, low union density and the lack of common law associational claims have made private sector employees' associational rights vulnerable. The unfortunate consequence is that American workers currently enjoy less associational freedoms than almost any other industrialized nation in the world.

The proposed federal Freedom of Association in the Workplace Act (FAWA) would not supplant existing constitutional and statutory protections at the federal and state level, but would provide a complementary and comprehensive statutory framework for all associational rights claims in the workplace. Such a law would provide additional protection for employee associational claims both procedurally and substantively, while simultaneously making consideration of the more difficult constitutional issues by courts unnecessary. If appropriately drafted and implemented, such a law would provide a uniform and understandable basis for guaranteeing workplace freedom of association.

More particulars for such federal legislation still need to be supplied and thought through. ${ }^{158}$ The purpose of this article, however, has been to highlight the technicolor nature of the right to association in American labor and employment law and to suggest that the time is ripe to bring some semblance of order through federal legislation to protect this foundational

concerning its relationship to the Rehabilitation Act of 1973. See 42 U.S.C. § 12201 (a) (2007). 157 This provision is again based on similar language in the Americans with Disabilities Act. Id. $\$ 1220$ I(b).

$15^{8}$ For instance, should an independent federal agency administratively hear such associational claims or should employees have the right to bring a private cause of action directly into state or federal court? What types of damages should be available and should incentives be set up so that employer and employees self-educate about the scope of associational rights in the workplace? 
[Vol. 96

right of a free society. ${ }^{159}$

159 "There are no countries in which associations are more needed, to prevent the despotism of faction or the arbitrary power of a prince, than those which are democratically constituted." Alexis de Tocoueville, Democracy in America 98 (Richard D. Heffner ed., New American Library, 1956) (1835). 